\title{
THE CHALLENGES OF FACULTATIVE ACCOUNTING SYSTEM IN THE STATE FORESTS
}

\section{KONRAD KOCHAŃSKI}

University of Szczecin, Faculty of Management and Economics of Services, POLAND

e-mail: konrad.kochanski@wzieu.pl

\begin{tabular}{l|l}
$\begin{array}{l}\text { RECEIVED } \\
\text { ACCEPTED }\end{array}$ & $\begin{array}{l}18 \text { January } 2018 \\
\text { 2 September } 2018\end{array}$ \\
CLASSIFICATION & M41 \\
KEYWORDS & $\begin{array}{l}\text { The main objective of the article is to analyse the basic tools of management accounting in the context of their } \\
\text { potential use in individual institutional units of the State Forests National Forest Holding. When identifying } \\
\text { facilitating and impeding determinants, the author has indicated the possibilities of applying the instruments in } \\
\text { question in the State Forests and after the analysis of the mission, strategy, vision, its map, functional tasks as } \\
\text { well as organizational structure, he has ultimately defined overarching challenges of the management account- } \\
\text { ing system in the State Forests National Forest Holding. }\end{array}$
\end{tabular}

\section{Introduction}

The rapidly changing environment poses new challenges to the State Forests National Forest Holding (SF NFH) in the scope of performing the fundamental - economic, but also social and protective function of forests. Despite the fact that it holds a statutory monopoly, it has to take into consideration market and social factors and, consequently, to recognize and satisfy multidimensional and often hardly measurable information needs of the 
environment. Therefore, the main objective of the article is to present the system of management accounting, the possibilities of its application and, ultimately, the challenges it will face in the State Forests in the context of generating useful information concerning the condition of forests, changing forests' conditions as well as forest management. Moreover, the author adopted the hypothesis that the system of management accounting can facilitate effective realization of sustainable forest management taking into account the present strategy and functional classification of SF NFH tasks.

The following research methods were used while developing the article: induction, deduction and inference. It was also necessary to carry out the detailed analysis of internal reports and other information resources of SF $\mathrm{NFH}$ as well as to conduct critical analysis of literature.

\section{The overview of the basic tools of management accounting in the State Forests}

The State Forests National Forest Holding (SF NFH) is an organisational unit without legal personality and is not a company within the meaning of Polish law. It has been established to manage specific property (particularly land, real estate and movables) within the scope of conducted forest management. It is characterized by largely developed organisational structure, in which one may distinguish: the Directorate General of the SF, the Regional Directorates of the SF, forest districts and other units without legal personality. Therefore, it should be clearly stated that the State Forests manage different units and at the same time are subject to management.

Management in each organisational unit is conducted through the realization of its basic functions and on the basis of the analysis of legal acts as well as available literature one may conclude that planning and organisation (forest arrangement plan, financial and economic plan) are particularly essential functions in the State Forests. As a result of strong centralisation, the form of top-down management dominates, despite the fact that the basic and statutorily independent organisational unit is a forest district.

The obligatory system of financial accounting is characterised by a range of shortcomings in the scope of generating useful information of managerial character. After all, this system is subject to realise primarily external informative function - for external environment. More about financial accounting in SF NFH in (Szczypa, 2016; Sadowska, 2015). Acquisition of useful management information, that is the one, which determines effective realization of information and decision-making processes depends, however, on the conscious or oftentimes intuitive application of the management accounting tools. Management accounting tools usually perform internal information function, whereas in the case of the SF NFH, the grounds for their application are clearly determined by the factors from both internal and external environment. The specific nature of forests resulting from their functions: productive, protective and social results in the fact that they are considered social commodities and, therefore, information generated by the selected tools of management accounting should be of both internal and external character, similarly as in the company directed at the concept of corporate social responsibility (CSR).

It seems reasonable to synthetically present premises of the application of management accounting tools, which could be effectively applied in the SF NFH that operates under specific conditions (Table 1).

It needs to be stressed that in table 1 the author reviewed the basic tools of management accounting with particular attention paid to information needs of financial, organizational and management character of the SF NFH. It is undoubtedly desirable to carry out further research in the context of determining the hierarchy of the described tools in relation to the mission, vision and strategy adopted by the State Forests as well as the current aspects of the operational character, influencing the financial and economic position. 
Table 1. The overview of the selected tools of management accounting to be applied in the State Forests

\begin{tabular}{|c|c|c|c|}
\hline No. & $\begin{array}{l}\text { Management } \\
\text { accounting tool }\end{array}$ & Grounds in favour of the application of the tool in the SF NFH & $\begin{array}{l}\text { The nature of the tool } \\
\text { for the SF NFH }\end{array}$ \\
\hline 1. & $\begin{array}{l}\text { Variable costs } \\
\text { account }\end{array}$ & $\begin{array}{l}\text { Shortcomings of the systematic costs account in the scope of the valuation of timber production } \\
\text { and its assortment ('standing timber' and 'logged timber'). The need to base calculation } \\
\text { of production costs on the criterion of 'sensitivity' in relation to production }\end{array}$ & Operational \\
\hline 1a. & $\begin{array}{l}\text { Multi-stage and } \\
\text { multi-block variable } \\
\text { costs account }\end{array}$ & $\begin{array}{l}\text { The need to structuralize the continuously rising fixed costs (indirect) and to determine } \\
\text { subsequent values of contribution margins resulting from covering individual stages of these } \\
\text { costs as well as estimating reliable viability of timber and its assortments' sales }\end{array}$ & Operational \\
\hline 2. & $\begin{array}{l}\text { Product life-cycle } \\
\text { costing }\end{array}$ & $\begin{array}{l}\text { Minimizing the shortcomings of the 'standing timber' method assuming the contractual } 100 \text { - } \\
\text { year old phase of forest management as well as the need for determining products life-cycles } \\
\text { (products, services and projects) of forest management and strategic management of their costs }\end{array}$ & Strategic \\
\hline 3. & Target costing & $\begin{array}{l}\text { The need to consider, within the framework of calculating the costs of wood production and its } \\
\text { assortments, the planned profitability (ensuring the implementation of priority } 6 \text { of the SF NFH } \\
\text { strategy) and, at the same time, the desired satisfaction of the recipients of forestry products }\end{array}$ & Strategic \\
\hline 4. & Kaizen costing & $\begin{array}{l}\text { The need to prepare tools in the case of the potential need for restructuring the selected } \\
\text { institutional units within the framework of the SF NFH or for adjusting the finances of the SF } \\
\text { NFH to new determinants of external environment (e.g. the need to pay } 2 \% \text { of revenues to the } \\
\text { state budget) }\end{array}$ & Strategic \\
\hline 5. & $\begin{array}{l}\text { Time-driven activity- } \\
\text { based costing (TD } \\
\text { ABC) }\end{array}$ & $\begin{array}{l}\text { The need for a new approach to calculating and presenting the continually rising indirect costs } \\
\text { resulting from the production of timber and its assortments as well as increasingly essential } \\
\text { non-productive (indirect) functions of forest. } \\
\text { The need to communicate this information to the environment in new perspectives (here in } \\
\text { processes) }\end{array}$ & Operational \\
\hline 6. & $\begin{array}{l}\text { Quality costs } \\
\text { calculation }\end{array}$ & $\begin{array}{l}\text { The need for quality cost management within the framework of the SF NFH. Focusing on the } \\
\text { costs of internal quality assurance within the framework of the implemented silviculture in } \\
\text { accordance with the principle } 1-10-100\end{array}$ & Operational \\
\hline 7. & Budgeting & $\begin{array}{l}\text { The need for the conscious finance management of individual institutional units within the } \\
\text { framework of the SF NFH, including primarily the implementation of planning and control cycle } \\
\text { of viability, liquidity and assets management in accordance with priority } 6 \text { of the State Forests } \\
\text { Strategy }\end{array}$ & $\begin{array}{l}\text { Operational/ } \\
\text { Strategic }\end{array}$ \\
\hline 8. & $\begin{array}{l}\text { Strategic balanced } \\
\text { scorecard }\end{array}$ & $\begin{array}{l}\text { Needs: } \\
\text { - to generate useful information on the implemented non-productive functions of forest, } \\
\text { - for measurements of the SF NFH achievements, } \\
\text { - for reliable valuation of forests, } \\
\text { - for assessments of institutional units of the SF NFH, } \\
\text { - for translation of the mission, vision and the adopted strategy into actions of operational } \\
\text { character determining the realization of its six priorities }\end{array}$ & Strategic \\
\hline 9. & Benchmarking & $\begin{array}{l}\text { The need to learn the best practices in the scope of finance, management and accounting from } \\
\text { the entities of a similar organizational structure, mission, vision and strategy, with particular } \\
\text { consideration to those aiming at implementing the concept of corporate social responsibility }\end{array}$ & Strategic \\
\hline
\end{tabular}

Source: author's own elaboration.

\section{The possibilities of implementing management accounting tools in the State Forests}

The implementation of management accounting tools in a given entity always depends on the determinants of facilitating or impeding character. The application of management accounting tools should always be preceded by the objective analysis of subjective factors existing in the SF NFH. Therefore, the following determinants are the subject of consideration:

1. The level of managers' awareness - it has considerable influence on the disclosure of the need determining the decision concerning the implementation of a tool or the selected tools of management accounting in the SF NFH. Creation by the SF NFH of the mission, vision, strategy and its map clearly indicates the appropriate level of manager's awareness of the entity. Nevertheless, it is desirable to familiarize the 
decision-making people of different institutional units with the solutions from the system of management accounting allowing for the realization of all the priorities included in the adopted strategy map both in the operational and strategic mode.

2. The adopted business activity register. The SF NFH is covered by the Accounting Act and, therefore, "bookkeeping" generates the most reliable information of financial and economic character in relation to the taxation forms provided for by the tax law. The accounting books are based on the appropriately organised documentation, the accounting records and reporting and in the context of the system of management accounting they constitute the fundamental system generating primary information, which are transformed in such a way to present useful secondary information only after the implementation of the selected tool.

3. Free resources required for implementation. In this area human factor is undoubtedly the most important. The suggested tools of management accounting are only the potential tools facilitating management in the SF NFH. It is only the appropriate knowledge, skills, social competence and experience of motivated employees that determine recognition of the need to use, appropriately implement and effectively apply the selected solutions. At the same time, the lack of sufficient motivation may lead to considerable human resources resistance. It may result from the inability to see the implementation need, benefits for the entity as well as those individual ones in the form of financial or non-financial incentives. Another essential determinant is the level of free financial resources. It refers to the so called friendly IT environment, determining the combination of the tools of the financial and management accounting system, as well as to other assets required for the functioning of structures responsible for conducting management accounting.

4. Potential costs and benefits resulting from the implementation of selected solutions. In this case, the fundamental activity is to specify only essential potential benefits and costs related to their achievement as well as to present them to decision-making people and the executive staff. Success, viewed in the context of effectiveness, depends on whether employees understand the need to implement the selected solution and, what is most important, what benefits it will bring for the SF NFH taking into consideration, at the same time, the costs resulting from both preparatory and implementation works and from the application of the selected tools.

5. Organizational structure - it constitutes the factor, which may facilitate or impede the implementation of the management accounting system. In the case of the SF NFH, it is an extensive structure, in which the basic institutional units (forest districts) are relatively autonomous in relation to management on the one hand and on the other hand, however, they are subordinate to the General Directorate of State Forests as a result of centralization. Therefore, the appropriate polarization of management accounting tools should be performed, dedicating the selected ones for the Directorate and for forest districts.

6. Due to political, legal and social factors, the SF NFH cannot be treated as an autonomous enterprise. Law regulations clearly determine that this statutory monopolist is not profit-oriented and, from the political perspective, indicate the need to pay $2 \%$ of revenue to the state budget. On the other hand, however, fulfilling free of charge social and protective functions by the State Forests results in the need to build appropriate communication based on the concept of corporate social responsibility considering also the principles of sustainable development. 
The indicated factors constitute the basis to formulate conclusions concerning the current challenges for the system of management accounting in the SF NFH which is the subject of further considerations.

\section{The challenges of management accounting in the State Forests}

Defining and undertaking key challenges for the management accounting tools in the State Forests should be structured in consistent and subsequent stages. The most important involve:

1. Diagnosis of the current knowledge on theoretical and implementing aspects of the management accounting system application in the SF NFH.

2. Financial and accounting audit in the State Forests, mainly of accounting books as a fundamental information system, indicating its dysfunctions as well as desired directions of changes. More about desired directions of changes in: (Szczypa, 2016).

3. Defining current information needs in the SF NFH, disclosure and recognition of new needs and the ways to satisfy them.

4. Management audit, in particular of the mission, vision, strategy, management methods, organizational structure as well as of the current management solutions.

5. Designing information system of the 'financial and management' character, implementation solutions, defining benefits and costs as well as securing necessary resources for realization.

6. Delegation of powers and responsibility, trainings as well as implementation of the accepted solutions dedicated to the General Directorate of State Forests and basic institutional units - forest districts when applying the selected implementation solutions.

7. Continuous monitoring of performed works, implementation of the planning and control cycle, including reporting, deviation analysis, identification of its reasons as well as undertaking remedial actions.

8. Continuous efforts to minimize the problem of information asymmetry, defined as the considerable discrepancy in the usefulness of the same information for financial and accounting teams, controllers and managers.

9. Popularization of developed solutions in the scope of the accounting system, including management accounting in the SF NFH in scientific environment and among practitioners, integration of both environments as well as looking for new solutions based on the accounting system.

It can be assumed that the major and complex challenge for the system of management accounting in the State Forests is acceptance and implementation of the discussed procedure into the mission, vision and strategy map of the SF NFH. The nature of management accounting instruments makes it possible to effectively conduct sustainable economy in the forests taking into account the primary economic function as well as hardly quantifiable and, at the same time, much more valuable social and protective functions. The challenge that the system faces should be correlated with the following priorities resulting from the strategy map (http://strategia.lasy.gov.pl):

Priority 1: Ensure forests preservation (forests as the most important element of environment).

Priority 2: Ensure the availability of forests for the society (forests as social goods).

Priority 3: Ensure a significant contribution of the State Forests into economic development (forestry as an important sector of economy and a creator of rural areas development). 
Priority 4: Become a modern, well managed and efficient organization.

Priority 5: Develop staff resources and competences as well as motivate them to implement the strategy.

Priority 6: Ensure the ability of business self-financing.

When analysing the above priorities we may conclude that the first three are of socio-economic character, whereas the other three are of financial and management nature. The challenge for management accounting in the SF NFH is undoubtedly the realization of priorities: 4,5 and 6 , in the first place, which will eventually result in indirect realization of priorities: 1,2 and 3 . The desirable action would be to present the system of management accounting on a clear strategy map of the State Forests combining all its elements.

Implementation of the discussed priorities by applying the said procedure of management accounting should be of operational character, which means that it is necessary to define submeasures, among which we may distinguish the following (Adamowicz, Szczypa, 2014):

- ex post, in tempora and ex ante quantification of the forest value,

- valuation of non-productive functions of forest; more about valuation in SF NFH in Nemś, Sadowska, Szczypa (2018),

- useful valuation of 'standing timber' and 'logged timber' production,

- managing finances of forest districts,

- multi-criteria assessment of institutional units of the SF NFH.

Moreover, specific activities should be related to the present functional classification of the State Forests tasks which would additionally increase the effectiveness of the whole accounting system, including management accounting.

\section{Conclusions}

Continuously evolving determinants of the environment (both external and internal) of the SF NFH as well as the increasing role of non-productive functions of forest in the context of conducting sustainable forestry economy result in the need to identify and understand current information needs as well as to recognize new needs and the ways to satisfy them. The considerations undertaken in the article enabled the author to positively verify the adopted hypothesis. They were also aimed at the implementation of the assumed goal through the analysis of the fundamental tools of management accounting in the context of their potential application in the State Forests for the selected institutional units. Additionally, when identifying the facilitating and impeding determinants, the author indicated the possibilities of applying the discussed instruments in the State Forests. Finally, after the analysis of the mission, vision, strategy, its map, functional tasks, organizational structure, etc. the author identified the major challenges of the management accounting system in the SF NFH.

\section{References}

Adamowicz, K., Szczypa, P. (2014). Możliwości wykorzystania rachunkowości zarządczej w Lasach Państwowych. Prace Naukowe Uniwersytetu Ekonomicznego we Wrocławiu, 344, 13-24.

http://strategia.lasy.gov.pl.

Nemś, M., Sadowska, B., Szczypa, P. (2018). Parametry i zasady wyceny nieruchomości leśnych w zarządzaniu. Wycena drzewostanów. Zeszyty Teoretyczne Rachunkowości, 96 (152), 109-121. 
Sadowska, B. (2015). Financial accounting tools of state forests in the area of the information needs of public, private and nongovernmental users, in the concept of sustainable forestry development. Acta Scientiarum Polonorum. Silvarum Colendarum Ratio et Industria Lignaria, 14 (2), 135-147. DOI: 10.17306/J.AFW.2015.2.13.

Szczypa, P. (2016). Forest districts accounting - current and future status in the light of the current state of science and knowledge in the field of accounting. Acta Scientiarum Polonorum. Silvarum Colendarum Ratio et Industria Lignaria, 15 (2), 97-103. DOI: 10.17306/J.AFW.2016.2.12.

Szczypa, P. (2016). Istota i rodzaje pożądanych zmian w rachunkowości Lasów Państwowych. Studia Ekonomiczne. Zeszyty Naukowe Uniwersytetu Ekonomicznego w Katowicach, 300, 174-182.

Cite this article aS: Kochański, K. (2018). The challenges of facultative accounting system in the state forests. European Journal of Service Management, 3 (27/2), 205-211. DOI: 10.18276/ejsm.2018.27/2-25. 